\title{
Effect of nasal packs on nasal obstruction and complications of septoplasty
}

\author{
Burun tamponlarının septoplasti komplikasyonları ve nazal obstrüksiyon üzerine etkisi

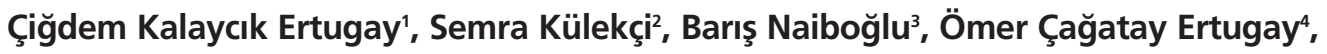 \\ Ersin Şengül ${ }^{3}$, Kerem Sami Kaya ${ }^{3}$ \\ ${ }^{1}$ Department of Otorbinolaryngology, Başkent University Istanbul Hospital, Istanbul, Turkey \\ ${ }^{2}$ Department of Otorbinolaryngology, Faculty of Medicine, Dumlupinar University, Kütabya, Turkey \\ ${ }^{3}$ Department of Otorbinolaryngology, Haydarpasa Numune Training and Research Hospital, Istanbul, Turkey \\ ${ }^{4}$ Department of Otorbinolaryngology, Zile Government Hospital, Tokat, Turkey
}

\begin{abstract}
Objective: We aimed to compare the use of Merocel nasal packs and airway integrated silicone nasal septal splints in the management of postoperative complications such as synechia formation, septal perforation, recurrent deviation and to evaluate nasal obstruction by using Nose Obstruction Symptom Evaluation scale following septoplasty.

Methods: Ninety-six patients who complained of nasal obstruction and underwent septoplasty under general anesthesia were enrolled in the study. The patients were randomly allocated into two groups as Group A (Merocel group) and Group B (silicone splint group). A follow-up visit was scheduled two months after surgical procedure and four different variables were investigated: (1) recurrent deviation (2) synechia (3) septal perforation; and (4) Nose Obstruction Symptom Evaluation scale score. Results: We found more frequent postoperative complications in the Merocel group but this finding was not statistically significant $(\mathrm{p}>0.05)$. Additionally comparison of Nose Obstruction Symptom Evaluation scale scores for nasal packing materials did not detect statistically significant difference between 2 groups ( $p>0.05$ ). Interestingly, we identified that in a subset of patients who had synechia formation, Nose Obstruction Symptom Evaluation scale scores had been significantly higher in comparison with the patients without synechia formation $(\mathrm{p}<0.05)$.

Conclusion: Although our data did not reach statistical significance, our study and previous reports support a better quality of life by using intranasal splints, but that needs further studies.
\end{abstract}

Keywords: Nasal obstruction, quality of life, complication.

Septoplasty is one of the most frequently performed surgical procedures to overcome nasal obstruction in otorhino-

\section{Özet}

Amaç: Merosel ve havayollu silikon nazal septal splint tamponlarının septoplasti sonrası oluşabilecek komplikasyonlar ve nazal obstrüksiyon üzerine etkisini karşılaştırmak amaçlanmış ve bu nedenle sineşi, septal perforasyon, rekürren deviasyon gibi postoperatif komplikasyonlar araştırılmış ve Nazal Obstrüksiyon Semptom Skalası kullanılarak nazal obstrüksiyon değerlendirmesi yapılmıştır.

Yöntem: Nazal obstrüksiyon şikayeti ile septoplasti operasyonu uygulanan 96 hasta çalıșmaya dahil edilmiştir. Hastalar randomize olarak Grup A (merosel grubu) ve Grup B (silikon splint grubu) diye ikiye ayrılmıştır. Cerrahiden iki ay sonra hastalar tekrar değerlendirilmiş ve 4 farklı değişken araştırılmıştır: (1) rekürren deviasyon, (2) sineşi, (3) septal perforasyon, (4) Nazal Obstrüksiyon Semptom Skalası.

Bulgular: Merosel grubunda daha çok postoperatif komplikasyon gözlenmiş ancak bu bulgu istatistiksel olarak anlamlı bulunmamıştır $(\mathrm{p}>0.05)$. Ayrıca iki grup arasındaki Nazal Obstrüksiyon Semptom Skalası skorları arasındaki fark istatistiksel olarak anlamlılık teşkil etmemiştir $(\mathrm{p}>0.05)$. İlginç olarak, sineşisi bulunan hastaların Nazal Obstrüksiyon Semptom Skalası skorlarının sineşisi olmayan hastalar ile karşışştırıldığında anlamlı oranda daha yüksek olduğu saptanmıştır $(\mathrm{p}<0.05)$.

Sonuç: Verilerimiz istatistiksel olarak anlamlılık teşkit etmese de, bizim çalışmamız ve önceki çalışmalar intranazal splint kullanımının yaşam kalitesi açısından daha iyi olduğunu göstermektedir ancak ilave çalışmalar gerekmektedir.

Anahtar sözcükler: Burun tıkanıklığı, yaşam kalitesi, komplikasyon.

laryngology clinics. Following septal surgery nasal packs are commonly inserted by surgeons to support septal flap appo-
Correspondence: Çiğdem Kalaycık Ertugay, MD. Department of Otorhinolaryngology, Başkent University Istanbul Hospital, Mahir İz Caddesi, No: 43, 34662, Istanbul, Turkey. e-mail: ckalaycik@gmail.com

Received: June 2, 2014; Accepted: June 24, 2014
Online available at: www.jmedupdates.org doi:10.2399/jmu.2014002006 QR code: 
sition as well as to close dead space between cartilage and mucoperichondrial flaps. In addition to prevention of nasal bleeding, packing is also used to avoid complications of septal surgery including hematoma, infection, abscess formation and perforation. ${ }^{[1]}$ A number of different nasal packing materials are available. The type of nasal packing material used depends on preference and experience of the surgeon. There is a disagreement over packing practices applied after routine nasal surgery. Although packing could prevent postoperative complications, some authors do not advocate use of any nasal packing because they propose nasal septal suturing as an alternative method owing to the fact that the pack itself can be the source of problems resulting in significant mucosal injury and loss of ciliary function. ${ }^{[2]}$

The otolaryngologists are searching for the optimal packing material, which should be easy to apply, cause minimal discomfort when in place, and minimize postoperative complications. We use routine Merocel or airway integrated silicone nasal septal splints which are the two nasal tamponade types in common use.

Nasal obstruction is a common complaint of patients with septal deviation. Nose Obstruction Symptom Evaluation (NOSE) scale is a disease spesific quality of life instrument for use in nasal obstruction which was validated by Stewart et al. ${ }^{[3]}$ Moreover, Kahveci et al. studied the efficiency of NOSE scale on patients, before and after septoplasty and noted it as an efficient tool to evaluate outcomes of septoplasty. ${ }^{[+]}$

There are many comparative studies about advantages and disadvantages nasal packings and the impact of septoplasty procedure on nasal blockage. ${ }^{[5-8]}$ The present study was designed to compare the use of Merocel nasal packs and silicone nasal septal splints with integral airway in the management of postoperative complications such as synechia formation, septal perforation, recurrent deviation and to evaluate nasal obstruction by using NOSE scale applied after septoplasty.

\section{Materials and Methods}

This prospective, observational study was conducted at Haydarpaşa Numune Training and Research Hospital which had been approved by the local ethical commitee. Informed consent was obtained from all patients.

Ninety-six patients who complained of nasal obstruction and underwent septoplasty under general anesthesia were enrolled in the study. Inclusion criteria were as follows: age $\geq 18$ years, septal deviation consistent with presenting symptom of nasal obstruction lasting at least for 3 months. The patients who had a history of nasal surgery, allergy, paranasal sinus pathologies or systemic disorders were excluded from the study.

Standard physical examination with anterior rhinoscopy and rigid nasal endoscopy were performed by a physician.

Surgical procedure was performed under general anesthesia by two of the authors. The surgical technique includes a hemitransfixation incision followed by creating subperichondrial and subperiostal tunnels via a closed approach and correction of the deviated segment with minimal excisions in order to try to reshape and mold the most deviated parts.

The patients were randomly allocated into two groups as Groups A (Merocel group) and B (silicone splint group). After septoplasty, bilateral anterior Merocel nasal packs (10 cm long in each nostril; Medtronic Xomed, Jacksonville, FL, USA) were applied to Group A, and silicone nasal septal splints with integral airway (in each nostril, sutured to septum; Invotec, Jacksonville, FL, USA) were applied to the other group (Group B) for postoperative packing. Both nasal packs were left in place for 2 days.

A follow-up visit was scheduled two months after surgical procedure and four different variables were investigated: (1) recurrent deviation (2) synechia (3) septal perforation; and (4) NOSE score. All the patients were asked to complete NOSE scale (Table 1). Sums of the answers

Table 1. Questionnaire of NOSE scale.

\begin{tabular}{|c|c|c|c|c|c|}
\hline & Not a problem & Very mild problem & Moderate problem & Fairly bad problem & Severe problem \\
\hline Nose obstruction and stuffiness & 0 & 1 & 2 & 3 & 4 \\
\hline Nose obstruction & 0 & 1 & 2 & 3 & 4 \\
\hline Trouble breathing through my nose & 0 & 1 & 2 & 3 & 4 \\
\hline Trouble sleeping & 0 & 1 & 2 & 3 & 4 \\
\hline $\begin{array}{l}\text { Unable to get enough air through } \\
\text { my nose during exercise or exertion }\end{array}$ & 0 & 1 & 2 & 3 & 4 \\
\hline
\end{tabular}


were multiplied by five to base the scale out of a possible score of 100 .

Surgical procedures and removal of the packs were applied by two of the authors. Analyses were performed by another author who was blinded to the patients and interventions.

\section{Statistical analysis}

Statistical analysis were performed using NCSS (Number Cruncher Statistical System) 2007\&PASS 2008 Statistical Software (Kaysville, Utah, USA) programme. MannWhitney U test, chi-square test and Fisher's exact chi-square test were used for comparing data. A p value $<0.05$ was considered statistically significant.

\section{Results}

Out of 96 patients included in the study, 26 (27.1\%) were female and $70(72.9 \%)$ were male, and the mean age was $33.54 \pm 10.86$ years. Group A (Merocel group) comprised of 44 patients while Group B (splint group) included 52 patients. There were no statistically significant difference between 2 groups in terms of age and sex. All of the participants successfully completed the survey. Recurrent deviation was determined in 23 patients (24\%), synechia in $17(17.7 \%)$ and septal perforation in 4 patients $(4.2 \%)$.

Comparison of postoperative complications of nasal packing materials is given in Table 2. Recurrent deviation was determined in 12 patients $(27.3 \%)$ in Group A compared with 11 patients (21.2\%) in Group B. This difference between 2 groups was not statistically significant ( $p>0.05$ ).

Synechia was observed in 9 patients $(20.5 \%)$ in Group A, and in 8 patients (15.4\%) in Group B. This difference between 2 groups was not statistically significant $(\mathrm{p}>0.05)$.

Septal perforation was determined in 3 patients $(6.8 \%)$ in Group A, and 1 patient (1.9\%) in Group B. This differ-
Table 2. Comparison of postoperative complications for the nasal packing materials.

\begin{tabular}{lccc}
\hline & $\begin{array}{c}\text { Silicone splint } \\
\text { group (n=52) }\end{array}$ & $\begin{array}{c}\text { Merocel } \\
\text { group (n=44) }\end{array}$ & $\begin{array}{c}\mathbf{p} \\
\text { value }\end{array}$ \\
\hline Postoperative deviation & $11(21.2 \%)$ & $12(27.3 \%)$ & 0.484 \\
Postoperative synechia & $8(15.4 \%)$ & $9(20.5 \%)$ & 0.517 \\
Postoperative perforation & $1(1.9 \%)$ & $3(\% 6.8 \%)$ & 0.330 \\
\hline
\end{tabular}

ence between 2 groups was not statistically significant $(\mathrm{p}>0.05)$.

Although our data did not reach statistical significance, they did demonstrate that postoperative complications had been more frequent in the Merocel group.

Comparison of NOSE scores for nasal packing materials did not demonstrate statistical significance between 2 groups ( $\mathrm{p}>0.05)$ (Table 3$)$.

In the subset of patients who had synechia, NOSE scores were significantly higher in comparison with patients without synechia $(\mathrm{p}=0.039)$.

There were no statistically significant differences between patients with and without septal perforation in terms of NOSE scores $(\mathrm{p}>0.05)$ (Table 3$)$.

We could not find significant correlation between synechia formation and septal perforation $(\mathrm{p}>0.05)$.

\section{Discussion}

Nasal packing is a relatively common procedure used after septoplasty. Although a number of different nasal packing materials had been described in the literature, there is a lack of consensus regarding the ideal material. In addition, some authors advocate nasal septal suturing as an alternative method. Recently many authors have been using intranasal splints routinely following septoplasty in that they might be associated with less morbidity as they main-

Table 3. Findings regarding the NOSE scale.

\begin{tabular}{|c|c|c|c|c|}
\hline & & \multicolumn{2}{|c|}{ NOSE scale } & \multirow[t]{2}{*}{$p$ value } \\
\hline & & Mean $\pm S S$ & Median & \\
\hline \multirow[t]{2}{*}{ Nasal pack } & Silicone splint & $18.17 \pm 17.62$ & 10 & 0.376 \\
\hline & Merocel & $20.11 \pm 17.50$ & 15 & \\
\hline \multirow[t]{2}{*}{ Postoperative synechia } & None & $17.53 \pm 17.35$ & 10 & 0.039 \\
\hline & Present & $26.17 \pm 16.91$ & 25 & \\
\hline Postoperative perforation & None & $18.91 \pm 17.72$ & 10 & 0.416 \\
\hline
\end{tabular}


tain septal stability and allow nasal breathing postoperatively through integral airways. ${ }^{[9,10]}$

For these reasons, in the present study, we compared two commonly used nasal tamponade types; Merocel and airway integrated silicone nasal septal splints. There are many comparative studies about advantages and disadvantages of these materials. ${ }^{[5-7]}$

There are various studies searching the impact of these materials on patient's discomfort and complications when in place. ${ }^{[11,12]}$ In one of these studies, Acioglu et al. investigated the effects of nasal packs with respect to pain, nasal fullness and postoperative bleeding following septoplasty and found that Merocel had had the highest pain potential during removal as well as the highest rate of bleeding afterwards. In contrast with the present study, they did not encounter any postoperative complications. ${ }^{[12]}$ Additionally Y1lmaz et al. studied 51 patients with anterior nasal packing and demonstrated that Merocel packings had caused temporary Eustachian dysfunction and a greater decrease in middle ear pressure compared with silicone nasal septal splints with integral airway. ${ }^{[1]]}$ An important contribution of this study is that we examined the impact of Merocel and silicone nasal septal splints with integral airway on postoperative complication rates. Postoperative deviation, septal perforation, and synechia formation were the parameters compared in our study. Although our data did not reach statistical significance, they did demonstrate that all these parameters had been more frequently seen in the Merocel group. Therefore further studies with larger groups should be performed.

Septal deviation is a common cause of symptoms of nasal obstruction. Surgical correction of a deviated septum, septoplasty, is the main treatment and it is generally performed to improve quality of life. NOSE scale is a disease spesific quality of life instrument for use in nasal obstruction and validated by Stewart et al. ${ }^{[3]}$ Kahveci et al. pointed out to the efficiency of NOSE scale on the patients who had septoplasty and noted that it as a promising and reliable method to evaluate the results of the septal surgery. ${ }^{[4]}$ In the present study, we also used NOSE scale to study our patients undergoing septoplasty but in contrast to previous reports, we compared the results regarding the type of nasal tamponade. Although splint group had better results following septoplasty in comparison with the Merocel group, intergroup difference did not reach statistical significance. If further studies with larger groups will be performed, this difference may reach statistical significance.
Interestingly, we identified that in the subset of patients who had synechia formation, NOSE scores had been significantly higher in comparison with the patients without synechia formation. However, this study has not been designed to test that hypothesis definitely, these results provide pilot data for a future study. Additionally we found that there had been no significant correlation between synechia formation and septal perforation.

The strength of this study is that we did not only investigate the effect of nasal packs on postoperative complications of patients who had undergone septoplasty but also their effects on the quality of life in terms of NOSE scale. On the other hand, absence of a control group could be a weakness of the study.

\section{Conclusion}

Nasal packs are widely used in the practice of otorhinolaryngology, especially following septoplasty which is one of the most frequently performed surgical procedures. We evaluated the effects of two commonly used nasal packing materials on postoperative complications and symptoms of nasal obstruction in terms of NOSE scale and concluded that although our data did not reach statistical significance, our study and previous reports support presence of better quality of life by using intranasal splints which should be substantiated with further studies.

Conflict of Interest: No conflicts declared.

\section{References}

1. Genç E, Ergin NT, Bilezikçi B. Comparison of suture and nasal packing in rabbit noses. Laryngosope 2004;144:639-45.

2. Shaw CL, Dymock RB, Cowin A, Wormald PJ. Effect of packing on nasal mucosa of sheep. J Laryngol Otol 2000;114:506-9.

3. Steward MG, Witsell DL, Smith TL, Weaver EM, Yueh B, Hannley MT. Development and validation of the Nasal Obstruction Symptom Evaluation (NOSE) scale. Otolaryngol Head Neck Surg 2004;130:157-63.

4. Kahveci OK, Miman MC, Yucel A, Yucedag F, Okue E, Altuntas A. The efficiency of Nose Obstrucion Symptom Evaluation (NOSE) scale on patients with nasal septal deviation. Auris Nasus Larynx 2012;39:275-9.

5. Yilmaz MS, Guven M, Elicora SS, Kaymaz R. An evaluation of biodegradable synthetic polyurethane foam in patients following septoplasty: a prospective randomized trial. Otolaryngol Head Neck Surg 2013;148:140-4.

6. Kim YS, Kim YH, Kim NH, Kim SH, Kim KR, Kim KS. A prospective, randomized, single-blinded controlled trial on biodegradable synthetic polyurethane foam as a packing material after septoplasty. Am J Rhinol Allergy 2011;25:e77-e79.

7. Prabhu V, Kaushik V, Rhodes S, Tay H. Foam nasal packs: a prospective, randomised, patient-controlled study. Rhinology 2007;45:242-7. 
8. Gandomi B, Bayat A, Kazemei T. Outcomes of septoplasty in young adults: the Nasal Obstruction Septoplasty Effectiveness study. Am J Otol 2010;31:189-92.

9. Aksoy E, Serin GM, Polat S, Kaytaz A. Removing intranasal splints after septal surgery. J Craniofac Surg 2011;22:1008-9.

10. Dubin MR, Pletcher SD. Postoperative packing after septoplasty: is it necessary? Otolaryngol Clin North Am 2009;42:279-85.
11. Yilmaz MS, Guven M, Buyukarslan DG, Kaymaz R, Erkorkmaz U. Do silicone nasal septal splints with integral airway reduce postoperative eustachian tube dysfunction? Otolaryngol Head Neck Surg 2012;146:141-5.

12. Acioglu E, Edizer DT, Yigit Ö, Onur F, Alkan Z. Nasal septal packing: which one? Eur Arch Otorhinolaryngol 2012;269:177781 .

This is an open access article distributed under the terms of the Creative Commons Attribution-NonCommercial-NoDerivs 3.0 Unported (CC BYNC-ND3.0) Licence (http://creativecommons.org/licenses/by-nc-nd/3.0/) which permits unrestricted noncommercial use, distribution, and reproduction in any medium, provided the original work is properly cited.

Please cite this article as: Kalaycık Ertugay Ç, Külekçi S, Naiboğlu B, Ertugay ÖÇ, Şengül E, Kaya KS. Effect of nasal packs on nasal obstruction and complications of septoplasty. J Med Updates 2014;4(2):56-60. 